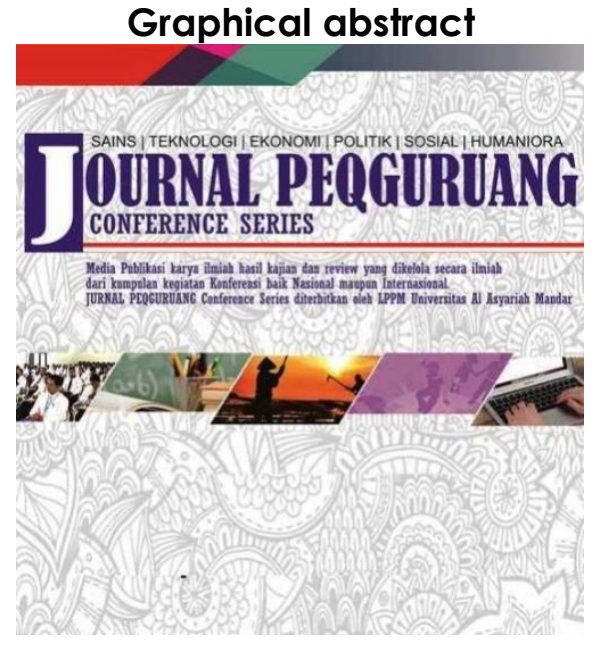

\section{PATOLOGI BIROKRASI DALAM PELAYANAN ADMINISTRASI DI DINAS KEPENDUDUKAN DAN CATATAN SIPIL KABUPATEN MAMASA.} \author{
Universitas Al Asyariah Mandar \\ ${ }^{1}$ watirina91723@gmail.com
${ }^{2}$ Syaeban@gmail.com
ㅁhmadmahoya@gmail.com
}

${ }^{1}$ Rinawati, ${ }^{2}$ Muhammad Syaeba, ${ }^{3}$ Ahmad Saleh Fakultas Ilmu-Ilmu Sosial Dan Ilmu Pemerintahan,

\begin{abstract}
Abstrak
Seiring perkembangan peradaban umat manusia tidak pernah lepas dari kehadiran institusi yang ada didalam masyarakat moderent yang dikenal sebagai birokrasi. Birokrasi mempunyai kewajiban untuk mensejahtarakan serta memberikan pemenuhan keburuhan rakyat atau masyarakat. Kehadiran birokrasi menjadi instrumen penting di dalam masyarakat. Patologi birokrasi lahir dari sebuah kesalahan seperti merit sytem dan exceed needs. Patologi birokrasi adalah penyakit atau bentuk perilaku birokrasi yang menyimpang dari nilai-nilai etis, aturan, dan ketentuan perundang-undangan serta norma-norma yang berlaku di dalam birokrasi. Penelitian dengan judul "Patologi birokrasi dalam pelaksanaan administrasi kependudukan di dinas kependudukan dan catatan sipil kabupaten mamasa" dengan rumusan masalah bagaimana patologi birokrasi dalam pelayanan pablik dan faktorfaktor penyebab terjadinya patologi birokrasi. Tujuan penelitian ini untuk mengetahui patologi birokrasi dan untuk mengetahui fator penyebab patologi birokrasi terhadap pelayanan pablik di dinas kependudukan dan catatan sipil Kabupaten Mamasa. Penelitian inimenggunakan metode deskriftif kualitatif dengan sumberdata yang digunakan adalah data-data primer dan data sekunder.
\end{abstract}

Kata kunci: Patologi Birokrasi, palaksanaan administrasi

Article history

DOI: http://dx.doi.org/10.35329/ip.v2i2.1551

Received : 07 September 2020 | Received in revised form : 17 September 2020 | Accepted :03 Oktober 2020 


\section{PENDAHULUAN}

Birokrasi kemudian bertugas menjalankan fungsifungsi pemerintah tersebut yakni dalam melakukan proses regulasi, distribusi, dan alokasi pelayanan dan pemberdayaan yang dapat dinikmati oleh seluruh masyarakat. Birokrasi sebagai sebuah sistem administrasi yang menjalankan fungsi-fungsi pemerintahan dituntut menjalankan perannya secara optimal. Hanya saja pada realitasnya birokrasi belum mampu menjalankan perannya dengan baik. Dalam permasalahan ini termuat pada persepsi masyarakat yang meyakini birokrasi kala ini justru menjadi penyebab dari bertele-telenya proses pemerintahan, tidak hanya dianggap sebagai suatu sistem yang berteletele, birokrasi juga dipandang sebagai sistem yang tidak bersahabat, diskriminatif, dan tidak transparan.

Beberapa hal kemudian digolongkan sebagai patologi (penyakit) birokrasi yang tentu sangat bertentangan dengan amanat Undang-Undang Nomor 25 Tahun. 2009, berbicara mengenai pelayanan publik, menjelaskan asas penyelenggaraan pelayanan publik dan perilaku pelaksana pelayanan publik. Dimana dalam peraturan perundang-undangan tersebut menjabarkan jika dalam penyelenggaraan pelayanan publik haruslah berdasarkan kepentingan umum, kesamaan hak, akuntabilitas, kemudahan, dan lainnya. Serta bertindak adil dan tidak diskriminatif, santun dan ramah, tidak mempersulit, dan tegas dalam penyelenggaraan pelayanan publik tersebut. Sebagaimana dalam hakekat instansi pemerintah adalah pelayanan kepada masyarakat, yakni tidaklah diadakan untuk melayani dirinya, melainkan untuk melayani rakyat, sehingga dengan kata lain adalah pelayan masyarakat (Hannan, S. 2019).

Siagian.P. Sondang bukunya menjelaskan tentang "patologi birikrasi adalah bagaimana menganalisis, mengidentivikasi dan terapinya". memaparkan terdapat 133 bentuk patologi birokrasi yang dikelompokkan kedalam 5 kategori berdasarkan penyebabnya, yakni:

a.) Patologi yang timbul karena persepsi dan gaya majerial para pejabat di lingkungan birokrasi;

b.) Patologi yang disebabkan karena kurangnya atau rendahnya pengetahuan dan keterampilan para petugas pelaksana berbagai kegiatan operasional;

c.) Patologi yang timbul karena tindakan para anggota birokrasi yang melanggar norma-norma hukum dan peraturan perundang-undangan yang berlaku;

d.) Patologi yang dimanifestasikan dalam perilaku para birokrat yang bersifat disfungsional atau negatif;

e.) Patologi yang merupakan akibat situasi internal dalam berbagai instansi dalam lingkungan pemerintahan.

Patologi birokrasi dengan berbagai macam gejala dan bentuknya telah lama menggerogoti sistem birokrasi pemerintah di Indonesia. Mengenai patologi atau penyakit birokrasi hendaknya bersumber dari bagaimana rekrutmen dan penempatan aparat yang berdasarkan keahlian jangan tidak berdasar dengan jenjang karir (merit system) dan profesionalisme kerja, tetapi lebih cenderung kepada ikatankedekatan emosiotisme maupun tindak kolusi. Serta keterlibatan birokrasi dalampolitik yang menyebabkan bercampur aduknya kepentingan- kepentingan yang mewarnai jalannya birokrasi di Indonesia sehingga melahirkan disorientasi terhadap profesionalisme kerja birokrasi dikarenakan seharusnya birokrasi bukanlah institusi lembaga yang mengedepankan kepentingan kelompok dan golongannya saja. Selain itu desain organisasi yang sangat Exceed Needs atau melebihi kebutuhan menyebabkan birokrasi tidak bekerja secara efisien.

Ada 3 (tiga) Aspek menurut A.M. Rusli (2014) untuk mencapai keberhasilan penyelenggaraan pelayanan publik secara garis besar yaitu: Bagaimana pola penyelenggaraan, Dukungan sumber daya manusia dan Kelembagaan. Berdasarkan observasi awal yang dilakukan penulis sebelum mengangkat judul ini ditemukan bahwa dalam pelayanan dasar yang ditentutkan sebelumnya yakni KTP, KK, dan Akta Kelahiran, beberapa masyarakat yang berhasil ditemui kemudian menjelaskan bahwa masih terdapat pungutanpungutan liar serta nepotisme dalam prosedur pelayanan administrasi kependudukan di Kabupaten Mamasa khususnya pada pelayanan yang paling padat yakni Kartu Tanda Penduduk (KTP). Beberapa lainnya menjelaskan terkait sikap aparatur yang kurang professional dalam menjalankan tugas serta terdapatnya calo-calo dalam pelayanan administrasi kependudukan tersebut. Beberapa informasi tersebut menggambarkan bahwa administrasi kependudukan khususnya di Kabupaten Mamasa masih tidak lepas dari berbagai bentuk patologi birokrasi.

Perilaku asal bos senag (ABS) di lingkup pejabat pemerintahan ini menjadi sebuah budaya paternalis yang hidup mengakar dalam masyarakat dengan struktur birokrasi Weberian, yang selanjutnya mengghasilkan penyakit birokrasi (Dwiyanto, 2011:61)

Pada dasarnya pelayanan administrasi kependudukan menjadi tanggungjawab seluruh elemen pemerintah, baik pusat, provinsi, maupun daerah. Namun, pelaksanaan secara teknis proses pelayanan administrasi kependudukan tersebut menjadi tanggungjawab dan wewenang dari pemerintah daerah kabupaten/kota. Sebagaimana diterangkan dalam peraturan pemerintah No.37 Tahun 2007 tentang Pelaksanaan Undang-Undang No.23 Tahun 2006 yang kemudian di revisi menjadi Undang-Undang No.24 Tahun 2013 tentang Administrasi Kependudukan.

Berdasarkan uraian tersebut di atas oleh karena itu penulis mengangkat judul skripsi dengan judul "Patologi Birokrasi dalam Pelaksanaan administrasi kependudukan di dinas kependudukan dan catatan sipil Kabupaten Mamasa” agar dapat Memahami patologi apa saja yang terjadi dalam proses pelaksanaan Administrasi Kependudukan tersebut serta faktor penyebabnya.

Robins mengutip konsep ideal max weber yang terdiri dari; Specialisasi pekerjaan, artinya semua 
pekerjaan dilakukan dalam kesederhanaan rutinitas dan pelaksanaan tugas dengan baik, Struktur kewenagan yang jelas, Seleksi dan basis kualifikasi yang tinggi, Pengambilan keputusan tentang selaksi dan promosi jabatan di tentukan oleh prestasi dan kemampuan, Pemberian sangsi di tetapkan untuk semua, tidak bersifat pribadi, Pegawai harus mengejar karir di organisasi, sehingga para pegawai lebih muda di promosikan untuk memangku jabatan sesuai keahliannya.

Birokrasi merupakan instrumen yang sangat penting dalam proses bernegara, sehingga adanya patologi didalam patologi tersebut menjadi suatu permasalahan yang sangat penting untuk ditemukan lalu dicari solusi terhadapnya.

Dari rumusan masalah diatas, maka penulis menetapkan tujuan penelitian sebagai berikut:

a.) Untuk mengetahui bentuk patologi yang terjadi dalam proses pelaksanaan pelayan publik di Dinas Kependudukan dan Catatan Sipil Kabupaten Mamasa.

b.) Untuk mengetahui faktor-faktor penyebab lahirnya patologi birokrasi dalam melaksanakan layanan publik di dinas kependudukan dan catatan sipil kabupaten mamasa.

\section{METODE PENELITIAN}

Penelitian ini dilaksanakan pada bulan Februari sampai dengan Bulan Maret, sesuai dengan judul yang di tetapkan yakni, Patologi Birokrasi dalam Pelaksanaan Administrasi Kependudukan di Kabupaten Mamasa. Maka penelitian ini mengambil lokasi dalam lingkup pelayanan administrasi di dinas kependudukan dan catatan sipil kabupaten mamasa.

\section{Teknik Pengumpulan Data}

Pengumpulan data dilakukan di berbagai tempat dan sumber dengan berbagai cara. Pengumpulan data penelitian ini menggunakan sumber data primer dan sumber data sekunder. Sumber primer adalah sumber data yang langsung diberikan kepada penulis, dan sumber data sekunder adalah sumber data yang diambil tidak langsung dari penulis, misalnya lewat orang lain dan dokumen dokumen yangsesuai dengan penelitian ini.

\section{Teknik Analisis Data}

Adapun teknik analisis data yang dilakukan penulis adalah dengan mengelola data menjadi sebuah informasi sehingga karakter data tersebut menjadi mudah untuk dibaca dan difahami.

Analisis data yang dipeloeh peneliti menggunakan teknik analisis kualitatif, yaitu dengan megolah data yang diperoleh lalau di analisis dan disajikan dalam bentuk tulisan. Teknik ini bertujuan untuk menggambarkan secara sistematis fakta-fakta yang di dapatkan di lapangan dan kemudian memperjelas gambaran hasil penelitian.

\section{HASIL DAN PEMBAHASAN}

\section{Bentuk-bentuk Patologi Birokrasi dalam Pelaksanaan Administrasi Kependudukan di Dinas Kependudukan dan Catatan Sipil Kabupaten Mamasa}

Birokrasi dalam sebuah Negara secara prinsipil merupakan suatu hal yang sangat penting. Hal ini disebabkan, birokrasi kemudian menjalankan fungsifungsi pemerintah yaitu regulasi, distribusi, alokasi dan pemberdayaan masyarakatPemerintah kemudian memegang kendali yang sangat besar dalam mengatur berbagai hidup dalam lingkungannya. Sehingga yang maksimal dari aparatur pemerintah dan seluruh stakeholdernya sangat di tuntut demi mencapai tujuan bernegara. Akan tetapi dalam pelaksanaannya hingga saat ini, pemerintah belum mampu secara maksimal menjalankan fungsi-fungsi tersebut. berbagai patologi lahir di dalam tubuh birokrasi di berbagai wilayah termasuk di Dinas Kependudukan dan Catatan Sipil Kabupaten Mamasa.

Untuk menjalankan proses pelayanan administrasi kependudukan, tentu dinas kependudukan dan pencatatan sipil menjadi pusat dari proses pelayanan tersebut. Adapun dinas kependudukan dan catatan sipil sendiri memiliki wewenang untuk melaksanakan dan mengambil kebijakan tentang segala hal terkait Administrasi Kependudukan. Hal ini meliputi pendataan, penertiban data dan dokumen kependudukan, serta perekaman dan pencetakan data dan dokumen kependudukan.

Akan tetapi, sebagai pusat dalam pelayanan administrasi kependudukan Khususnya di dinas kependudukan dan catatan sipil manjadi ujung dari proses pengurusan ataupun penerbitan dokumendokumen kependudukan terutama dokumen-dokumen kependudukan dasar yakni KTP, KK, dan Akta kelahiran. Oleh karena itu Dinas Kependudukan dan Pencatatan Sipil menjadi rentan terhadap berbagai jenis patologi birokrasi dalam hal pelayanan administrasi kependudukan.

Berdasarkan hasil penelitian yang dilakukan, maka ditemukan beberapa bentuk patologi birokrasi yang lahir dalam pelaksanaan administrasi kependudukan di Dinas Kependudukan dan Catatan Sipil Kabupaten Mamasa. Dari data dan informasi serta hasil wawancara yang dilakukan oleh peneliti, maka di dapat beberapa bentuk patologi yang masih menjangkit didalam Dinas Kependudukan dan Pencatatan Sipil itu sendiri. Adapun bentuk-bentuk patologi birokrasi tersebut adalah sebagai berikut: Tidak Cekatan dan Mutu Pelayanan yang Rendah. Kurang Disiplin (Indicipline), Pelayanan berbelit- belit, dan Sikap Aparatur yang tidak Responsif 


\section{Faktor-faktor Penyebab Terjadinya Patologi Birokrasi dalam Pelaksanaan Administrasi Kependudukan di Dinas Kependudukan dan Catatan Sipil Kabupaten Mamasa}

Patologi Birokrasi atau yang lebih dikenal dengan sebutan penyakit birokrasi tentu tidak lahir sendiri atau berdiri tunggal. lahirnya patologi birokrasi tentu disebabkan oleh berbagai hal atau dalam hal ini kita sebut sebagai faktor-faktor penyebab lahirnya patologi birokrasi. Faktor-faktor tersebut bisa disebabkan oleh sistem atau rangkaian sistem yang bermasalah, hal-hal di luar sistem, ataupun masalah-masalah lain terkait subjek maupun objek dari sebuah proses pelayanan publik yang ada.Berdasarkan kajian pustaka yang digunakan dan hasil penelitian yang dilakukan, maka dapat disimpulkan beberapa faktor penyebab lahinya atau terjadinya patologi birokrasi sebagai berikut:Lemahnya Faktor Moral, Lemahnya Pengawasan, Sanksi yang Tidak Tegas, dan Rendahnya Pengetahuan dan Keterampilan Aparatur

\section{SIMPULAN}

Penulis mengambil kesimpulan berdasarkan dari hasil penelitian yang telah dilakukan pada dinas kependudukan dan catatan sipil Kabupaten Mamasa terkait "Patologi Birokrasi dalam Pelaksanaan Administrasi Kependudukan di Kabupaten Mamasa", maka di temukan beberapa bentuk patologi birokrasi yang masih umum di jumpai didalam pemerintahan di tingkat kabupaten. Adapun bentuk-bentuk patologi tersebut secara umum ada 6 bentuk: 1) Tidak cekatan dan mutu pelayanan yang rendah; 2) Kurang Disiplin; 3) Diskriminasi/perbedaan pelayanan; 4) Pelayanan Berbelit-belit; 5) Sikap Aparatur yang Tidak Responsif; 6) Gratifikasi.

Berbagai bentuk patologi tersebut tentu menjadi sebuah masalah yang sangat krusial untuk dilakukan pencarian solusi terhadapnya. Hal yang lebih penting untuk di kaji bersama bahwa beberapa dari patologi tersebut khususnya yang terlihat jelas dan berdampak besar terhadap kepuasaan masyarakat justru tidak difahami oleh masyarakat dan aparatur pemerintah dan menganggap bahwa Patologi tersebut bukanlah sebuah bentuk Patologi. Hal ini bisa dilihat pada contoh kasus "uang terima kasih" yang secara teori ialah bagian dari gratifikasi namun dianggap hal yang sah-sah saja. Oleh karena itu pengedukasian penting dilakukan baik untuk masyarakat maupun aparatur itu sendiri.

Lahirnya beberapa bentuk patologi diatas juga tentunya tidak lepas dari faktor-faktor yang mempengaruhi. Adapun Faktor-faktor tersebut diantaranya: 1) Lemahnya faktor moral; 2) Lemahnya Pengawasan; 3) Sanksi yang tidak tegas; 4) Gaji rendah.

Beberapa deskripsi di atas kemudian sudah cukup untuk menjelaskan bahwa birokrasi kita yang semakin modern sesuai dengan perkembangan zaman nyatanya masih saja terjangkit berbagai penyakit dan tentunya harus segera ditemukan solusi dan terapinya.
Penulis tuliskan berdasar dari hasil penelitian dan observasi yang dilakukan ialah sebagai berikut:

a.) Perlunya dilakukan pelatihan intensif terkait pentingnya moral dan pemahaman terhadap tugas dan tanggung jawab sebagai aparat Negara.

b.) Pemerintah sebaiknya lebih transparan terkait berbagai standar operasional prosedur kepada masyarakat sertamelibatkan masyarakat dalam proses pengawasan aparaturNegara. Hal ini di harapkan dapat memberikan kemudahankepada masyarakat sebagai pemohon dan mengurangi semaksimal mungkin terjadinya patologi birokrasi dilingkup dinas kependudukan dan catatan sipil kabupaten Mamasa.

c.) Perlunya inovasi-inovasi baru baik dalam rangka peningkatan pengawasan maupun inovasi terkait peningkatan pelayanan guna mempermudah masyarakat dalam mengakses layanan publik khususnya KTP, KK, dan Akta Kelahiran seperti peningkatan pemanfaatan Eletronic Government hingga ketingkat desa, perampingan prosedur penerbitan dokumen dan lain-lain. Hal ini tentu dapat meminimalisir kesan berbelit- belit pada birokrasi dan juga meminimalisir penggunaan waktu yang selalu saja menjadi salah satu indikator utama kepuasan masyarakat.

\section{DAFTAR PUSTAKA}

Dwiyanto, Agus, dkk. (2008). Reformasi Birokrasi Publik dilndonesia. Yogyakarta: Gadjah Mada University Press.

Hannan, S. (2019). ANALISIS PELAYANAN ADMINISTRASI DI KELURAHAN BANGGAE KABUPATEN MAJENE (STUDI KASUS PEMBUATAN SURAT KETERANGAN TIDAK MAMPU DAN SURAT AHLI WARIS). MITZAL (Demokrasi, Komunikasi dan Budaya): Jurnal Ilmu Pemerintahan dan Ilmu Komunikasi, 1(1).

Rusli, A.M. (2014). Patologi Birokrasi dalam Pelayanan Pertanahan di Kota Makassar program pasca sarjanan Administrasi Publik. Universitas Hasanuddin.

Robbins, P. Stephen. (1994). Teori Organisasi: Struktur, Desain dan Aplikasi. Jakarta: Arcan.

Siagian, Sondang P. (1994). Patologi Birokrasi: Analisis, Identifikasi, dan Terapinya. Jakarta: Ghalia Indonesia.

Sinambella, Poltak, Lijan, (2006). Reformasi Pelayanan Publik: Teori Kebijakan dan Implementasi. Jakarta: PT. Bumi Aksara. 
Undang-Undang No. 25 Tahun 2009 tentang Pelayanan

Publik

Undang-Undang No. 24 Tahun 2013 tentang Administrasi Kependudukan

Syaeba, M. (2018). Pengaruh Kepemimpinan Kepala Sekolah, Motivasi Kerja Guru Dan Budaya Sekolah Terhadap Kedisiplinan Siswa Di Kabupaten Polewali Mandar. Pepatudzu: Media Pendidikan dan Sosial Kemasyarakatan, 13(1), 43-56. 